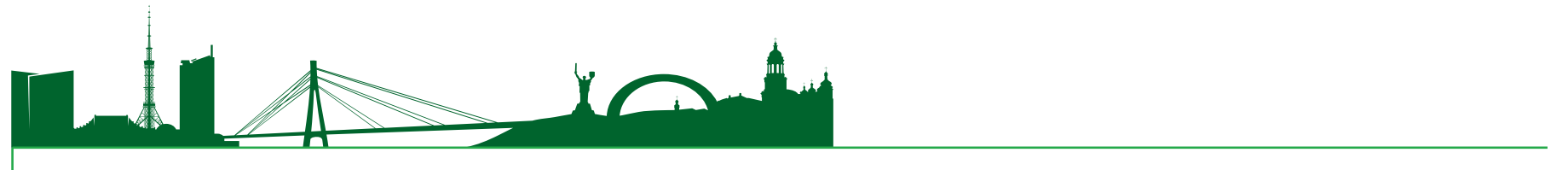

УДК 699.841+624.042.7

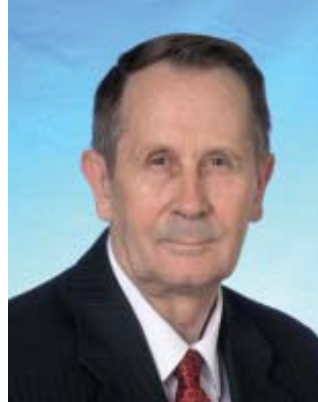

НЕМЧИНОВ Ю.І.

Д-р технічних наук, проф., перший заступник директора інституту 3 наукової роботи, ДП «Державний науководослідний інститут будівельних конструкцій», м. Київ, Україна, e-mail:yu.nemch@ndibk.gov.ua, тел.: + 38 (050) 469-35-77,

ORCID: 0000-0002-6618-125X

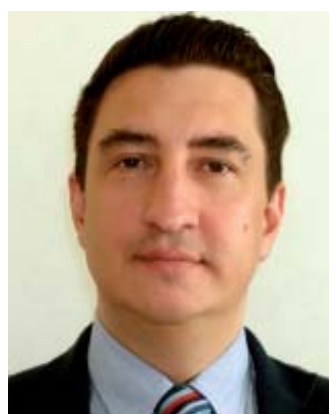

\section{БАБІК К.М.}

Канд. технічних наук, зав. лаб., ДП «Державний науководослідний інститут будівельних конструкцій», м. Київ, Україна, e-mail:k.babik@ndibk.gov.ua, тел.: +38 (050) 415-37-58, ORCID: 0000-0002-8763-510X

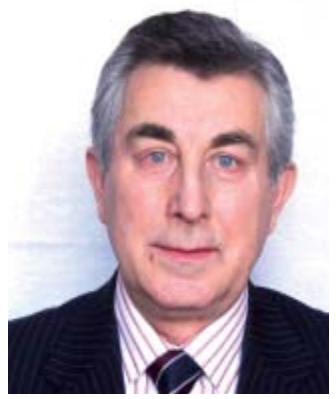

\section{КЕНДЗЕРА О.В.}

Канд. фізико-математичних наук, член-кор. Національної академії наук України, заст. директора, Інститут геофізики iм. C.I. Субботина НАН України, м. Київ, Україна, e-mail: kendzera@igph.kiev.ua, тел.: + 38 (044) 423-81-43, ORCID: 0000-0003-0691-0227

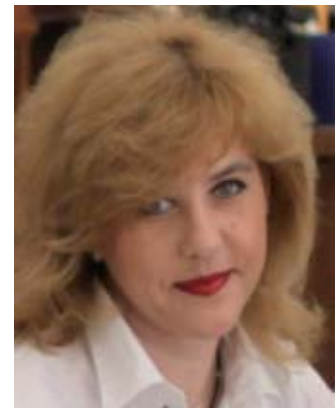

\section{ПЕТРАШ C.B.}

Канд. технічних наук, доц. Одеська державна академія будівництва та архітектури, м. Одеса, Україна, e-mail:SvetlanaPetrash@ukr.net, тел.: +38 (068) 593-49-38,

ORCID: 0000-0002-8567-3962

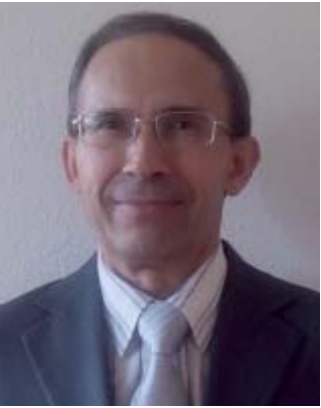

МАР'СНКОВ М.Г.

Д-р технічних наук, зав. відділом, ДП «Державний науководослідний інститут будівельних конструкцій», м. Київ, Україна, e-mail: n.maryenkov@ndibk.gov.ua, тел.: + 38 (050) 415-36-03,

ORCID: 0000-0001-8613-877X

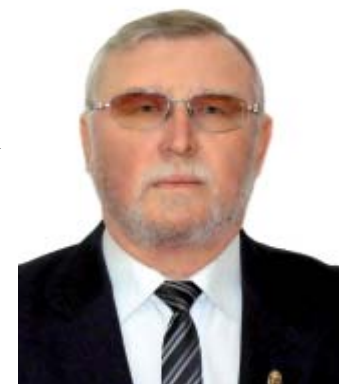

СГУПОВ К.В.

Д-р технічних наук, проф., директор НДI фундаментальних і прикладних досліджень, Одеський національний морський університет, м. Одеса, Україна, e-mail: yegupov.k@gmail.com, тел.: + 38 (097) 238-02-08,

ORCID: 0000-0002-8342-820X

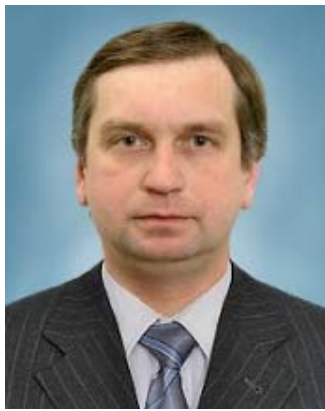

\section{ШЕХОВЦОВ I.В.}

Канд. технічних наук, доц., Одеська державна академія будівництва та архітектури, м. Одеса, Україна, e-mail:ogasanis@ukr.net, тел.: +38 (067) 628-79-17

ORCID: 0000-0003-3664-0723

\title{
НОРМАТИВНІ АКТИ В СФЕРІ СЕЙСМОСТІЙКОГО БУ ДІВНИЦТВА НОВОГО ПОКОЛІННЯ. ЗМІНА № 1 ДБН В.1.1-12:2014 «БУ ДІВНИЦТВО У СЕЙСМІЧНИХ РАЙОНАХ УКРАЇНИ»
}

\section{АНОТАЦІЯ}

Представлені основні положення Зміни № 1 ДБН В.1.1-12:2014 «Будівництво у сейсмічних районах України» [1], що враховують досвід та сучасні тенденції проектування будівель і споруд в сейсмічних районах інтенсивністю від 6-ти до 10-ти балів згідно 3 ДСТУ Б В.1.1-28:2010 «Шкала сейсмічної інтенсив- ності» [6] та ДСТУ-Н Б ЕN 1998-1:2010 «Еврокод 8. Проектування сейсмостійких конструкцій. Частина 1. Загальні правила, сейсмічні дії, правила щодо споруд (EN 1998-1:2004, IDT)» [4].

В Зміні № 1 ДБН В.1.1-12:2014 наведені вимоги щодо використання карт загального сейсмічного районування (ОСР-2004) території України, зокре- 
ма карти ОСР-2004-С при проектуванні об'єктів із значним класом наслідків (відповідальності) СС3 для будівель житлового та громадського призначення, що не ідентифікуются як об'єкти підвищеної небезпеки відповідно до Закону України «Про об'єкти підвищеної небезпеки».

Результати експериментально-теоретичних досліджень, виконаних ДП НДІБК протягом 2015-2017 років, сприяли розробленню системних вимог щодо визначення сейсмічних навантажень на багатоповерхові та висотні (висотою 73,5 м та вище) будівлі, а також вимог щодо проектування малоповерхових (до 3 поверхів) будівель 3 несучими стінами із газобетонних блоків автоклавного тверднення в залежності від розрахункової сейсмічності будівельного майданчика (6, 7 і 8 балів).

Наведені вимоги щодо використання газобетонних блоків марки D 400 за середньою густиною і класом за міцністю на стиск C 2,5 і марки D 300 за середньою густиною і класом за міцністю на стиск C 2,0; допустимих значень перекосів поверхів малоповерхових будівель з несучими стінами із ніздрюватого бетону для трьох рівнів (С3, ПЗ, МР3); коефіцієнту $k_{1}$, що враховує непружні деформації та локальні пошкодження конструкцій при землетрусах.

КАЮЧОВІ СЛОВА: Зміна № 1 ДБН В.1.1-12:2014, карти 3СР-2004, висотні будівлі, будівлі з несучими стінами із ніздрюватого бетону

\section{НОРМАТИВНЫЕ АКТЫ НОВОГО ПОКОАЕНИЯ В СФЕРЕ СЕЙСМОСТОЙКОГО СТРОИТЕАЬСТВА. ИЗМЕНЕНИЕ № 1 ДБН В.1.12:2014 «СТРОИТЕЛЬСТВО В СЕЙСМИЧЕСКИХ РАЙОНАХ УКРАИНЫ»}

НЕМЧИНОВ Ю.И. Д-р технических наук, проф., первый зам. директора института, ГП «Научноисследовательский институт строительных конструкций»,

г. Киев, Украина,

e-mail: yu.nemch@ndibk.gov.ua,

тел.:+38 (050) 469-35-77,

ORCID: 0000-0002-6618-125X

МАРЬЕНКОВ Н.Г. Д-р технических наук, зав. отделом, ГП «Научно-исследовательский институт строительных конструкций»,

г. Киев, Украина,

e-mail: n.maryenkov@ndibk.gov.ua,

тел.: +38 (050) 415-36-03,

ORCID: 0000-0001-8613-877X

БАБИК К.Н. Канд. технических наук, зав. лаб., ГП «Научно-исследовательский институт строительных конструкций»,

г. Киев, Украина,

e-mail:k.babik@ndibk.gov.ua,

тел.: +38 (050) 415-37-58,

ORCID: 0000-0002-8763-510X

ЕГУПОВ К.В. Д-р технических наук, проф., директор НИИ фундаментальных и прикладных иссле- дований, Одесский национальный морской университет,

г. Одесса, Украина,

e-mail: yegupov.k@gmail.com,

тел.:+38 (097) 238-02-08,

ORCID: 0000-0002-8342-820X

КЕНДЗЕРА А.В. Канд. физико-математических наук, член-кор. Национальной академии наук Украины, зам. директора, Институт геофизики им. С.И. Субботина НАН Украины,

г. Киев, Украина,

e-mail: kendzera@igph.kiev.ua,

тел.: +38 (044) 423-81-43,

ORCID: 0000-0003-0691-0227

ШЕХОВЦОВ И.В. Канд. технических наук, доцент, Одесская государственная академия строительства и архитектуры,

г. Одесса, Украина,

e-mail: ogasanis@ukr.net,

тел.: +38 (067) 628-79-17,

ORCID: 0000-0003-3664-0723

ПЕТРАШ С.В. Канд. технических наук, доцент, Одесская государственная академия строительства и архитектуры,

г. Одесса, Украина,

e-mail: SvetlanaPetrash@ukr.net,

тел.: + 38 (068) 593-49-38,

ORCID: 0000-0002-8567-3962

\section{АННОТАЦИЯ}

Представлены основные положения Изменения № 1 ДБН В.1.1-12:2014 «Строительство в сейсмических районах Украины» [1], которые учитывают опыт и современные тенденции проектирования зданий и сооружений в сейсмических районах интенсивностью от 6-ти до 10-ти баллов по ДСТУ Б В.1.1-28 «Шкала сейсмической интенсивности» [6] и ДСТУ-Н Б ЕN 1998-1:2010 «Еврокод 8. Проектирование сейсмостойких конструкций. Часть 1. Общие правила, сейсмические действия, правила про сооружения (EN 1998-1:2004, IDT)» [4].

В Изменении № 1 ДБН В.1.1-12:2014 приведены требования по использованию карт общего сейсмического районирования (ОСР-2004) территории Украины, в частности, карты ОСР-2004-С при проектировании объектов класса последствий (ответственности) CС3 для зданий жилого и общественного назначения, которые не идентифицируются как объекты повышенной опасности в соответствии с Законом Украины «Об объектах повышенной опасности».

Результаты экспериментально-теоретических исследований, выполненные ГП НИИСК на протяжении 2015-2017 гг., позволили разработать системные требования по определению сейсмических нагрузок на многоэтажные и высотные (высотой 73,5 м и выше) здания, а также требования по проектированию малоэтажных (до 3 этажей) зданий с несущими стенами из газобетонных блоков авто- 


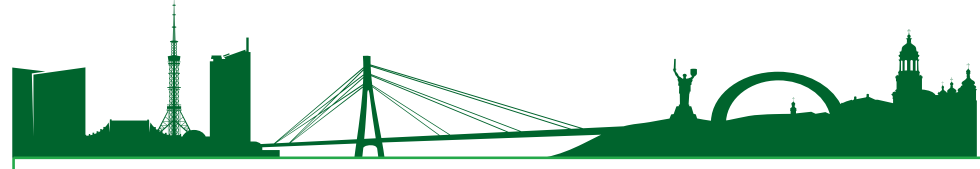

клавного твердения в зависимости от расчётной сейсмичности строительной площадки $(6,7$ и 8 бал入OB).

Приведены требования по применению газобетонных блоков марки D 400 по средней плотности и классу прочности на сжатие C 2,5 и марки D 300 по средней плотности и классу прочности на сжатие С 2,0; допустимым значениям перекосов этажей малоэтажных зданий с несущими стенами из ячеистого бетона для трёх уровней (С3, ПЗ, МРЗ); коэффициенту $k_{1}$, учитывающему неупругие деформации и локальные повреждения конструкций при землетрясениях.

КЛЮЧЕВЫЕ СЛОВА: Изменение №1 ДБН В.1.1-12, карты ОСР-2004, высотные здания, здания с несущими стенами из ячеистого бетона

\section{NEW GENERATION REGULATORY ACTS ON THE EARTHQUAKE RESISTANT CONSTRUCTION. AMENDMENT No. 1 TO DBN V.1.-1-12: 2014 «CONSTRUCTION IN SEISMIC REGIONS OF UKRAINE»}

NEMCHYNOV Iu.I. Dr., Prof., the First Deputy Dir. for Scientific Work, SE «The State Research Institute of Building Constructions»,

Kyiv, Ukraine,

e-mail: yu.nemch@ndibk.gov.ua,

tel.: +38 (050) 469-35-77,

ORCID: 0000-0002-6618-125X

MARIENKOV M.G. Dr, Head of Department, SE «The State Research Institute of Building Constructions»,

Kyiv, Ukraine,

e-mail: n.maryenkov@ndibk.gov.ua,

tel.: +38 (050) 415-36-03,

ORCID: 0000-0001-8613-877X

BABIK K.M. PhD, Head of Laboratory, SE «The State Research Institute of Building Constructions»,

Kyiv, Ukraine,

e-mail: k.babik@ndibk.gov.ua,

tel.: + 38 (050) 415-37-58,

ORCID: 0000-0002-8763-510X

YEGUPOV K.V. Dr., Prof., Director, the Research Institute for Fundamental \& Applied Studies of Odessa National Maritime University,

Odessa, Ukraine,

e-mail: yegupov.k@gmail.com,

tel.: + 38 (097) 238-02-08,

ORCID: 0000-0002-8342-820X

KENDZERA O.V. PhD, Deputy Dir., S.I. Subbotin Institute of Geophysics, National Academy, Sciences of Ukraine,

Kyiv, Ukraine,

e-mail: kendzera@igph.kiev.ua,

tel.: +38 (044) 423-81-43,

ORCID: 0000-0003-0691-0227

SHEKHOVTSOV I.V. PhD, Ass. Prof., Odessa State Academy of Civil Engineering and Architecture,

Odessa, Ukraine,

e-mail: ogasanis@ukr.net, tel.: +38 (067) 628-79-17,

ORCID: 0000-0003-3664-0723

PETRASH S.V. PhD, Ass. Prof., Odessa State Academy of Civil Engineering and Architecture,

Odessa, Ukraine,

e-mail: SvetlanaPetrash@ukr.net,

tel.: + 38 (068) 593-49-38,

ORCID: 0000-0002-8567-3962

\section{ABSTRACT}

The provisions of Amendment No. 1 to DBN V.1.-1-12: 2014 «Construction in seismic regions of Ukraine» [1] are presented. The norms take into account the experience and modern trends of buildings and structures design in seismic regions with intensities of 6 to 10 points according to DSTU B.1.1-28:2010 «Scale of seismic intensity» [6] and DSTU-N B EN 1998-1:2010 «Eurocode 8. Design of structures for earthquake resistance - Part 1: General rules, seismic actions and rules for buildings (EN 1998-1:2004, IDT)» [4]. In Amendment No.1 to $\mathrm{DBN}$ V.1.-1-12:2014 the requirements are given as to the use of the maps of general seismic zoning (GSZ-2004) of the territory of Ukraine, in particular GSZ-2004-C map, when designing the objects of significant CC3 consequences (importance) class for residential and public buildings, which are not identified as the highly hazardous objects in compliance with the law of Ukraine «On objects of higher risk».

The experimental and theoretical researches conducted at the NIISK during 2015-2017 have allowed the development of requirements for determining the seismic loads on the multistory and high-rise (with heights of $73.5 \mathrm{~m}$ and more) buildings, as well as of recommendations for designing the low-rise (up to 3 storeys) buildings with the bearing walls of autoclaved aerated concrete blocks according to the design building site seismicity $(6,7$ and 8 points).

The requirements are formulated as to the use of aerated concrete blocks with the characteristics of D 400 C 2.5 and D 300 C 2.0 (average density and compressive strength); allowable values of floor skewing in lowrise buildings with cellular concrete bearing walls for three levels of earthquakes (SZ - weak earthquake, PZ - design earthquake and MDE - maximum design earthquake); the coefficient $k_{l}$, which takes into account the structures inelastic deformations and local damages at the earthquakes.

KEY WORDS: Amendment No 1, DBN B.1.1-12, GSZ-2004 maps use, high-rise buildings and facilities, buildings with cellular concrete bearing walls

\section{1. ВСТУПНІ ПОЛОЖЕННЯ}

У 2015 році в місті Одесі на ювілейній Десятій конференції в сфері сейсмостійкого будівництва була представлена нова редакція ДБН В.1.1-12:2014 [1], що містять:

- основні положення щодо сейсмічної безпеки будівель та споруд, що засновані на 
багаторічному досвіді аналізу наслідків катастрофічних землетрусів і використовуються у відповідних нормах в сфері сейсмостійкого будівництва різних країн світу;

- сучасні методи проектування сейсмостійких будівель, що наведені у відповідних нормативних документах країн США, Канади, Японії, країн Европи. Наведені методи отримали загальну назву «Nonlinear Pushover Analysis» (нелінійний метод, заснований на аналізі послідовного руйнування елементів конструкцій під дією поперечного навантаження), а прийнятий у ньому підхід до проектування «Performance based seismic engineering» розглядається як «Проектування сейсмостійких конструкцій із заданими параметрами сейсмостійкості» або «Проектування на основі робочих характеристик»;

- рівні безпеки споруд, що відповідають певним рівням сейсмічних впливів:

- «Immediate Ocсupance» - слабкий землетрус (C3);

- «Life Safety» - проектний землетрус (ПЗ);

- «Structural Stability» - максимальний розрахунковий землетрус (MP3).

- нормовані спектри впливів та порядок визначення сейсмічних навантажень;

- сейсмічне зонування;

- основи проектування будівель, що відповідають вимогам ДСТУ-Н Б ЕN 1998-1:2010 [4];

- основні конструктивні вимоги щодо забезпечення сейсмостійкості при проектуванні будівель та споруд, зокрема:

- забезпечення простоти конструкції;

- забезпечення однорідності і симетричності будівлі у плані та за висотою;

- забезпечення однакового опору будівлі сейсмічним навантаженням у двох горизонтальних напрямах;

- зменшення негативного впливу крутильних коливань;

- створення горизонтальних діафрагм у рівні міжповерхових перекриттів;

- обов'язкових вимог до фундаментів будівлі;

- застосування будівель 3 «гнучким поверхом» (особливості та недоліки);

- уникнення співударяння будівель при землетрусі тощо.

2. МЕТОДИ РОЗРАХУНКУ БУДІВЕЛЬ, ЩО ВСТАНОВ ЕНІ В ДСТУ-Н Б ЕN 1998-1:2010 [4]

У ДСТУ-Н Б ЕN 1998-1:2010 [4] встановлені наступні методи розрахунку, що використовуються для вирішення задач сейсмостійкості будівель:

- лінійний статичний аналіз (звичайно називається методом поперечних сил);

- модальний аналіз спектру реакції (використовують як референтний метод лінійнодинамічного аналізу, у якому застосовується лінійно-пружна модель конструкції та проектний спектр реакції. У нормативному полі України і країн СНД цей метод називають «спектральним методом»);

- нелінійний статичний аналіз (відомий як «розрахунок на граничну міцність» («Nonlinear Pushover Analysis»). Метод заснований на аналізі послідовності руйнування елементів конструкцій під дією зовнішнього навантаження на конструкцію);

- нелінійний динамічний аналіз (покроковий аналіз акселерограм землетрусів в часі з урахуванням розгляду усіх відомих нелінійностей (Non-linear Time History (dynamic) Analysis)).

Серед вищевказаних методів розрахунку найбільш розповсюдженим $є$ метод нелінійного статичного аналізу, як найбільш прийнятний для інженерного застосування теорії сейсмостійкості.

\section{1 Нелінійний статичний аналіз (Nonlinear} Pushover Analysis)

Основним принципом методу є оцінка цільових (проектних) переміщень конструкцій, що можуть виникнути при сейсмічному впливі, що здійснюється із застосуванням розрахунку на основі послідовного аналізу руйнування конструкцій під дією зовнішнього навантаження (аналіз граничної міцності будівлі) [7 - 9].

Для практичного використання розроблені процедури оцінки сейсмічної реакції на основі спектрів сейсмічних впливів i перетворення системи 3 багатьма ступенями свободи на систему з однією еквівалентною масою $M_{\text {екв }}$ і узагальненою горизонтальною жорсткістю $K_{\text {екв. }}$ Схема такого перетворення наведена на рис. 1.
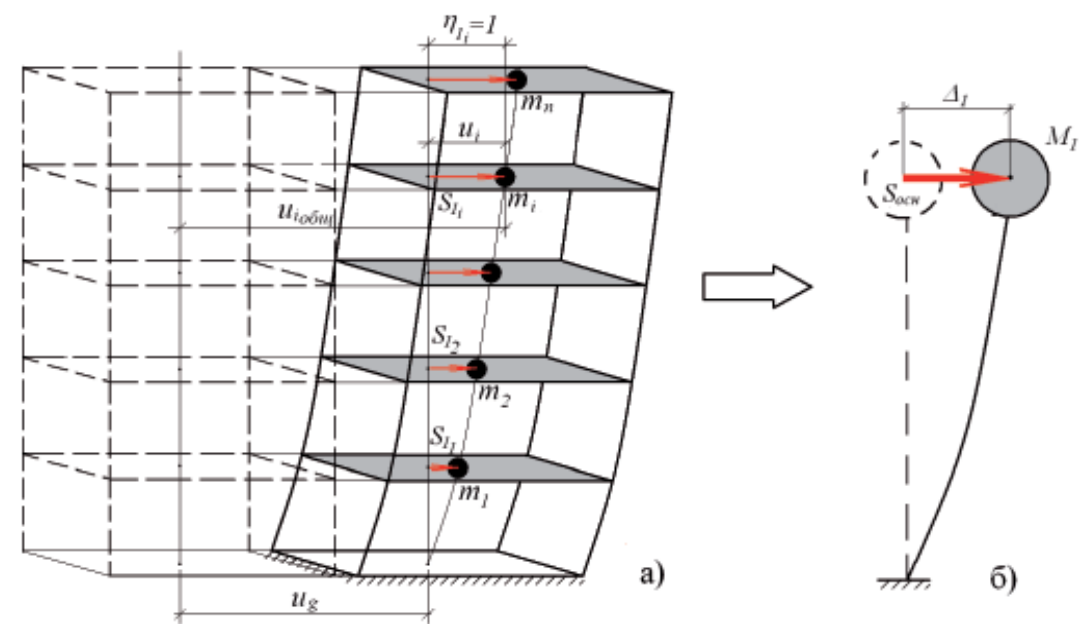

Рис. 1. Схема перетворення багатомасової системи на еквівалентну систему з одним ступенем свободи 


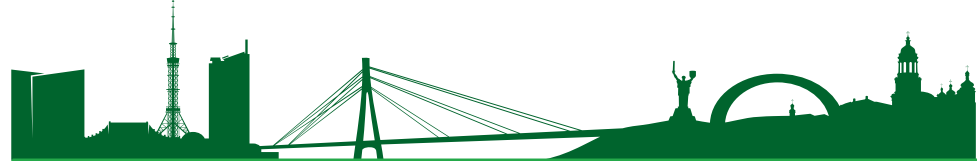

Мається на увазі, що система з багатьма ступенями свободи (Multiple-Degree-of- Freedom (MDOF)) перетворюється на систему з одним ступенем свободи (Single-Degree-of- Freedom (SDOF)). Основний принцип такого перетворення визначають кілька відомих схем, зокрема:

- метод спектру несучої здатності (ATC-40) [7];

- метод коефіцієнтів переміщення (FEMA 356) [10];

- процедура постійного коефіцієнта пластичності (Chopra \&Goel) [11].

Якщо позначити величину еквівалентної маси $M_{\text {экв }}=M^{*}$ i горизонтальну жорсткість $K_{\text {екв }}=K^{*}$ одномасової системи, а також припустити, що основна форма переміщень буде відповідати коливанням за першою формою багатомасової консольної системи, як це наведено на рис. 1, то період коливань еквівалентної системи конструкцій Т можна записати наступним чином:

$$
\begin{gathered}
T_{\text {экв }}=2 \pi \sqrt{\frac{M^{*}}{K^{*}}}, \\
K_{\text {экв }}=K^{*}=\frac{F_{y}^{*}}{u_{y}^{*}} .
\end{gathered}
$$

У формулі (2) індекс «у» (yield) характеризує граничну міцність (умовну текучість) конструкції, що стосується еквівалентної системи з одним ступенем свободи, а величина $u_{y}^{*}$ стосується переміщень, що відповідає такому ж стану конструкцій.

Методологія, що використовує процедуру Спектра несучої здатності будівлі, наведена у ДСТУ-Н Б ЕN 1998-1:2010 [4] та у відповідних нормативних документах країн СІІА, а також програмно втілена у поширених розрахункових комплексах. Сучасні методики розрахунку дозволяють враховувати несиметричність будівель і споруд у плані та за висотою, вплив вищих форм коливань для висотних будівель і протяжних споруд, взаємодію в системі «основа - фундамент - надземна частина будівлі (споруди)».

Прийнята процедура рішення задачі складається 3 послідовних етапів, наведених у доповіді [12]. На іiі основі доопрацьовано відповідні норми в сфері будівництва в сейсмічних районах, що були представлені у низці публікацій $[1,3,5,19]$.

\section{2 Особливості положень ДБН В.1.1-12:2014}

ДБН В.1.1-12:2014 [1] встановлюють обов'язкові вимоги, яких потрібно дотримуватися при проектуванні, будівництві, реконструкції та експлуатації будівель і споруд різного призначення, що зводяться на майданчиках з сейсмічністю 6 балів і вище за шкалою сейсмічної інтенсивності [6].

Особливостями положень ДБН В.1.1-12:2014 [1] 6:

- визначення сейсмічних навантажень 3 ураху- ванням нелінійного деформування матеріалів і конструкцій;

- застосування нелінійного розрахунку конструкцій 3 використанням методу спектра несучої здатності відповідно до ДСТУ-Н Б ЕN 1998-1:2010 [4];

- удосконалення підходу до застосування карт Загального сейсмічного районування території України 3 урахуванням класу наслідків (відповідальності) будівель і споруд, що проектуються у сейсмічних районах України;

- уточнення вимог до сейсмічного мікрорайонування будівельних майданчиків та розрахунків будівель і споруд на сейсмічні впливи, задані акселерограмами землетрусів;

- встановлення конструктивних вимог до будівель і споруд, що проектуються в районах із сейсмічністю будівельного майданчика 6 балів;

- встановлення вимог щодо розміщення на будівлях висотою понад 70 м і на об'єктах експериментального будівництва станцій інженерносейсмометричних спостережень;

- встановлення вимог щодо динамічної паспортизації об'єктів заввишки понад 16 поверхів;

- встановлення диференційованих показників перекосів поверхів в залежності від рівнів сейсмічних впливів, що відповідають слабким (С3), проектним (ПЗ) та максимальним розрахунковим землетрусам (МР3);

- орієнтація на широке застосування програмних комплексів оцінки сейсмостійкості;

- уточнені вимоги щодо проектування сейсмостійких гідротехнічних споруд;

- нові положення шодо проектування укосів;

- нові положення щодо проектування систем сейсмоізоляції будівель різного призначення.

\section{3. ЗМІНА № 1 ДБН В.1.1-12:2014 «БУДІВНИЦТВО У СЕЙСМІЧНИХ РАЙОНАХ УКРАЇНИ»}

Зміна № 1 ДБН В.1.1-12:2014 спрямована на удосконалення оцінки рівнів сейсмічного впливу на будівлі і споруди з урахуванням досвіду проектування сейсмостійких будівель, накопиченого з 2006 року по теперішній час.

Призначення і завдання розроблення Зміни № 1 ДБН В.1.1-12:2014 полягало в забезпеченні проектування сейсмостійких багатоповерхових i висотних будівель та споруд незначного (CC1), середнього (CC2) та значного (CC3) класів наслідків (відповідальності), а також малоповерхових будівель з несучими стінами із газобетонних блоків автоклавного тверднення.

Зміна № 1 ДБН В.1.1-12:2014 містить актуалізований перелік нормативних посилань i назв населених пунктів України, наведених у Додатку А (Таблиця А.1) та Додатку Б (на Картах Загального сейсмічного районування ЗСР-2004). 


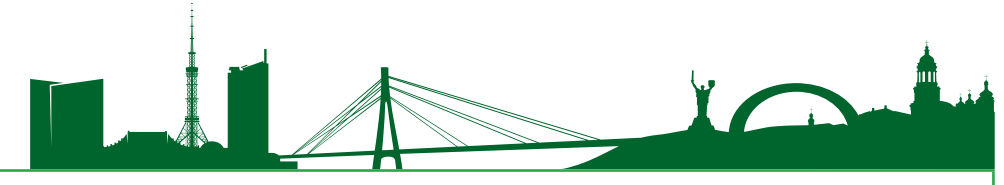

Основні положення Зміни № 1 ДБН В.1.1-12:2014 стосуються розділу 5 ДБН В.1.1-12:2014, зокрема, абзац 6 пункта 5.1.1 викладено у новій редакції:

«5.1.1 Комплект карт 3СР-2004 території України складається з:

- карти 3СР-2004-А, що відповідає 10\%-ій ймовірності перевищення нормативної сейсмічної інтенсивності упродовж 50 років i середнім періодом повторюваності таких інтенсивностей один раз на 500 років. Карту слід застосовувати при проектуванні будівель i споруд із незначним (CC1) класом наслідків (відповідальності) згідно 3 ДБН В.1.2-14, а також із середнім (CC2) та значним (CС3) класами наслідків (відповідальності) згідно 3 ДБН В.1.2-14 для будівель заввишки до $73,5 \mathrm{м}$;

- карти 3СР-2004-В, що відповідає 5\%-ій ймовірності перевищення нормативної сейсмічної інтенсивності упродовж 50 років i середнім періодом повторюваності таких інтенсивностей один раз на 1000 років. Карту 3СР-2004-В слід застосовувати при проектуванні будівель і споруд із середнім (СС2) та будівель із значним (СС3) класом наслідків (відповідальності) заввишки від 73,5 м і вище;

- карти 3СР-2004-С, що відповідає 1\%-ій ймовірності перевищення нормативної сейсмічної інтенсивності упродовж 50 років i середнім періодом повторюваності таких інтенсивностей один раз на 5000 років. Карту 3СР-2004-С слід застосовувати при проектуванні будівель і споруд, що відносяться до об'єктів підвищеної небезпеки, та відповідають значному (СС3) класу наслідків (відповідальності) згідно з ДБН В.1.2-14;

- детальної карти 3СР-2004-А0, що відповідає 39\%-ій ймовірності перевищення нормативної сейсмічної інтенсивності упродовж 50 років і середнім періодам повторюваності таких інтенсивностей один раз на 100 років. Відповідні карти слід застосовувати при проектуванні тільки в АР Крим та Одеській області для будівель і споруд із незначним (CC1) класом наслідків (відповідальності)».

Зміни, що внесені у ДБН В.1.1-12:2014, стосуються застосування карт Загального сейсмічного районування типу 3СР-2004-А, 3СР-2004-В та ЗСР2004-С, зокрема:

- карта «А» призначена для застосування не лише для будівель із середнім (СС2) класом наслідку (відповідальності) (як наведено у ДБН В.1.1-12:2014), але також і для будівель заввишки до 73,5 м, що відносяться до будівель із значним (СС3) класом наслідків (відповідальності) відповідно до ДБН В.1.2-14 [13];

- карта «В» застосовується для проектування будівель і споруд не лише із середнім (СС2)

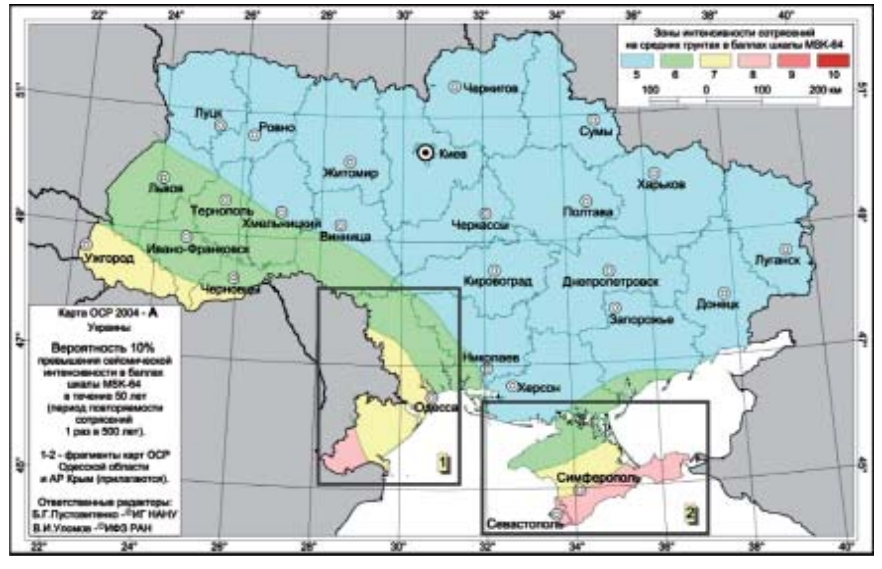

Рис. 2. Карта Загального сейсмічного районування 3СР-2004-А території України

класом наслідків (відповідальності) (як наведено у ДБН В.1.1-12:2014), але і для будівель заввишки від 73,5 м і вище із значним (СС3) класом наслідків (відповідальності) відповідно до ДБН В.1.2-14 [13];

- карту «С» потрібно застосовувати при проектуванні будівель і споруд, що відносяться до об'єктів підвищеної небезпеки, із значним (СС3) класом наслідків (відповідальності) відповідно до ДБН В.1.2-14. Відповідно до Закону України «Про об'єкти підвищеної небезпеки» [14] до об'єктів підвищеної небезпеки не відносяться житлові та громадські будівлі із значним (СС3) класом наслідків (відповідальності). Тому при проектуванні житлових і громадських будівель заввишки до 73,5 м потрібно застосовувати карту 3СР2004-А, а при проектуванні будівель із значним (СС3) класом наслідків (відповідальності) заввишки 73,5 м і вище потрібно застосовувати карту 3СР-2004-В.

Карту 3СР-2004-С потрібно застосовувати, наприклад, при проектуванні таких об'єктів:

- об'єкти нафтової, газової, металургійної, хімічної, оборонної та інших галузей промисловості;

- об'єкти гідро- і теплоенергетики;

- мости і тунелі на дорогах вищої категорії або протяжністю понад 1000 м або $з$ прольотом понад 300 м і т. п.

Відповідно до ДСТУ-Н Б ЕN 1998-1:2010 [4] житлові та громадські будівлі класу важливості II відповідають класу наслідків відповідальності (СС2), встановленого у ДСТУ-Н Б ЕN 1990:2008. Класи важливості будівель відповідно до ДСТУ-Н Б ЕN 1998-1:2010 [4], наведено у табл. 1.

Карту А0 потрібно застосовувати при проектуванні лише в АР Крим та Одеській області для будівель i споруд із незначним (CC1) класом наслідків (відповідальності) відповідно до ДБН В.1.2-14 [13].

У новій редакції викладено і пункт 5.2.2, а саме:

«5.2.2 Проектуючи будівлі і споруди із знач- 


\begin{tabular}{|c|c|}
\hline \multicolumn{2}{|c|}{ Таблиця 1. Класи важливості будівель } \\
\hline $\begin{array}{c}\text { Класи } \\
\text { важли- } \\
\text { вості }\end{array}$ & Будівлі \\
\hline I & $\begin{array}{c}\text { Будівлі другорядної важливості для громадської безпеки, } \\
\text { наприклад, сільськогосподарські та інші будівлі }\end{array}$ \\
\hline II & Звичайні будівлі, не віднесені до інших категорій \\
\hline III & $\begin{array}{c}\text { Будівлі, сейсмостійкість яких важлива з точки зору наслідків, } \\
\text { пов’язаних з руйнуваннями, наприклад, школи, залу засідань, } \\
\text { культурних закладів і так далі }\end{array}$ \\
\hline IV & $\begin{array}{c}\text { Будівлі, цілісність яких під час землетрусу життєво важлива для } \\
\text { цивільного захисту, наприклад, лікарні, пожежні депо, } \\
\text { електростанції і так далі }\end{array}$ \\
\hline
\end{tabular}

Примітка: Класи важливості I, II, III чи IV приблизно відповідають наслідкам класів CC1, CC2 та CC3, відповідно, визначеним у Додатку B EN 1990:2002

ним (СС3) класом наслідків (відповідальності) слід виконувати науково-технічний супровід відповідно до положень ДБН В.1.2-5.».

Порівняно з ДБН В.1.1-12:2014 [1], внесений Зміною № 1 ДБН В.1.1-12:2014 пункт 5.2 .2 розширений, оскільки стосується лише нових конструктивних схем будівель і споруд без зазначення класу наслідків (відповідальності) (CC3).

Другий і третій абзаци пункту 6.1.1 також викладені у новій редакції, а саме:

«Сейсмічні навантаження, що відповідають C3, можуть використовуватися при проектуванні будівель і споруд із незначним (CC1) класом наслідків (відповідальності) і категорії складності І з використанням детальних карт 3СР-2004-А0 (для територій АР Крим та Одеської області).

Сейсмічні навантаження, що відповідають ПЗ, повинні використовуватися при проектуванні будівель і споруд iз незначним (CC1), середнім (CC2) та значним (CC3) класами наслідків (відповідальності) згідно $з$ ДБН В.1.2-14 із застосуванням карт 3СР-2004-A, a також із середнім (CC2) та значним (СС3) класами наслідків (відповідальності) згідно з ДБН В.1.2-14 із застосуванням карт 3СР-2004-В (для території України) або детальних карт 3СР-2004-А i 3СР-2004-В (для територій АР Крим та Одеської області) відповідно до 5.1.1.».

Нова редакція пункту 6.1.1 обумовлена зміною назв рівнів сейсмічних впливів, а також змінами редакції пункту 5.1.1, пояснення до яких наведені вище.

Зміною № 1 ДБН В.1.112:2014, внесені зміни до таблиці 6.3, що наведена у новій редакції, а саме:
«Таблиця 6.3 - Коефіцієнт $k_{1}$, що враховує непружні деформації та локальні пошкодження елементів будівель (споруд)

\begin{tabular}{|c|c|c|c|}
\hline \multirow[t]{2}{*}{ Конструктивні рішення систем і несучих елементів } & \multicolumn{3}{|c|}{$\begin{array}{c}\text { Значення } k_{1} \text { за } \\
\text { сейсмічності } \\
\text { будівельного } \\
\text { майданчику, } \\
\text { балів }\end{array}$} \\
\hline & 6 & $7-8$ & 9 \\
\hline $\begin{array}{l}\text { Будівлі і споруди, в яких пошкодження або непружні } \\
\text { деформації не допускаються, а також при визначенні } \\
\text { додаткових моментів від вертикальних навантажень (див. } \\
\text { п. 6.3.6, 6.3.7) }\end{array}$ & \multicolumn{3}{|c|}{1,0} \\
\hline \multirow{4}{*}{$\begin{array}{l}\text { Будівлі і споруди, в конструкціях яких можуть бути допущені } \\
\text { залишкові деформації і пошкодження, що ускладнюють } \\
\text { нормальну експлуатацію при забезпеченні безпеки людей і } \\
\text { збереження обладнання, що зводяться: } \\
\text { - } \text { зі стальним каркасом; } \\
\text { - } \text { із залізобетонним каркасом без вертикальних діафрагм або } \\
\text { ядер жорсткості; } \\
\text { із залізобетонним каркасом з вертикальними діафрагмами } \\
\text { або ядрами жорсткості; }\end{array}$} & & & \\
\hline & 0,25 & 0,25 & 0,3 \\
\hline & 0,25 & 0,35 & 0,45 \\
\hline & 0,25 & 0,3 & 0,4 \\
\hline $\begin{array}{l}\text { - зі стінами } 3 \text { монолітного залізобетону та } 3 \text { великих } \\
\text { залізобетонних панелей; }\end{array}$ & 0,25 & 0,25 & 0,35 \\
\hline - 3 несучими стінами із крупних блоків і каркасно-кам'яними; & 0,25 & 0,35 & 0,4 \\
\hline - $\quad$ з несучими стінами з кам’яної або цегляної кладки; & 0,25 & 0,4 & 0,45 \\
\hline $\begin{array}{l}\text { - } з \text { несучими стінами з блоків із ніздрюватого бетону } \\
\text { автоклавного тверднення; }\end{array}$ & 0,5 & 0,5 & 0,6 \\
\hline - $\quad$ с системами сейсмоізоляції & 0,25 & $1 / R_{\mu}$ & $1 / R_{\mu}$ \\
\hline $\begin{array}{l}\text { Елементи будівель, що розраховуються на «місцеві» сейсмічні } \\
\text { навантаження (заповнення каркасів і перегородки в } \\
\text { розрахунках із площини, парапети, козирки тощо) }\end{array}$ & 0,4 & 0,5 & 0,6 \\
\hline $\begin{array}{l}\text { Будівлі і споруди, в конструкціях яких можуть бути допущені } \\
\text { значні залишкові деформації, тріщини, пошкодження окремих } \\
\text { елементів, їх зміщення, що тимчасово призупиняє нормальну } \\
\text { експлуатацію при забезпеченні безпеки людей }\end{array}$ & 0,2 & 0,2 & 0,3 \\
\hline \multicolumn{3}{|c|}{$\begin{array}{l}\text { Примітка 1. Значення коефіцієнта редукції } R_{\mu} \text { визначають за методикою відповідно } \\
\text { до додатку Г. }\end{array}$} & овідно \\
\hline
\end{tabular}


Зміни, що внесені до таблиці 6.3, відносяться до конструктивних рішень систем і несучих елементів будівлі 3 несучими стінами із газобетонних блоків ніздрюватого бетону автоклавного тверднення. Підставою для внесення відповідних змін є отримані результати комплексних випробувань елементів та фрагментів будівель із зазначених матеріалів на дію сейсмічних навантажень, що виконані в ДП НДІБК протягом 2014-2016 років [17].

Основна мета досліджень полягала у визначенні несучої здатності стін будівель із газобетонних блоків ніздрюватого бетону автоклавного тверднення висотою до 3-х поверхів при сумісній дії вертикальних статичних та горизонтальних сейсмічних навантажень на будівлю. В якості об'єкта досліджень було обрано триповерховий житловий будинок з несучими стінами із газобетону, розробленого інститутом УКРНДПІЦИВІАЬБУ Д [18].

Послідовність оцінки сейсмостійкості конструкцій включала:

- аналіз конструктивного рішення будівлі з несучими стінами 3 блоків автоклавного тверднення марки D 400 за середньою густиною і класом за міцністю на стиск С 2,5 і блоків марки D 300 за середньою густиною і класом за міцністю на стиск С 2,0;

- розрахунок триповерхового будинку на дію сейсмічних навантажень, встановлених у ДБН В.1.1-12:2014;

- експериментальну оцінку міцності розчину, фрагментів газобетонних блоків, натурних простінків і кладки;

- визначення фізико-механічних характеристик газобетонних блоків, розчину і кладки;

- оцінку впливу залізобетонних сердечників на збільшення міцності простінків;

- отримання експериментальних діаграм деформування «вертикальне навантаження - деформації стискання» кладки, «горизонтальне навантаження - кути зсуву (перекоси)» фрагменту як у разі відсутності залізобетонних включень (сердечників), так i при їх наявності в несучій системі простінків;

- визначення несучої здатності простінків при сумісній дії вертикальних i горизонтальних сейсмічних навантажень, що відповідають сейсмічним навантаженням 7 та 8 балів.

Для визначення максимального значення допустимого перекосу несучих стін і визначення їх сейсмостійкості проведені випробування двох однако- вих простінків (в масштабі 1:1) житлового триповерхового будинку при сумісній дії вертикальних та горизонтальних (еквівалентних сейсмічним) навантажень.

Один простінок ПР-3 (рис. 3) в масштабі 1:1 (3 блоків 600 мм $\times 400$ мм $\times 200$ мм) був випробуваний на дію постійного вертикального (160 кН) і ступінчатого горизонтального навантаження 3 кроком 5 кН, що відповідає сейсмічним 7 та 8 балам.

Другий простінок ПР-3 в масштабі 1:1 (кладка 3 розмірами 600 мм $\times 400$ мм $\times 200$ мм) був випробуваний на дію постійного вертикального (160 кН) i знакоперемінних (три цикла випробувань) горизонтальних навантажень, що відповідають сейсмічним 7 та 8 балам.

В результаті проведених досліджень було сформульовано наступні висновки:

1. Будівництво житлових будинків 3 несучими стінами із газобетонних блоків автоклавного тверднення марки D 400 за середньою густиною і $з$ класом міцності на стиск не менше ніж С2,5 можливо висотою до 3-х поверхів в районах сейсмічністю 6 та 7 балів. При розрахунковій сейсмічності майданчика будівництва 8 балів висота житлових будинків не повинна перевищувати 2 поверхи 3 використанням в несучих стінах залізобетонних сердечників.

2. Будівництво житлових будинків 3 несучими стінами із газобетонних блоків класу за

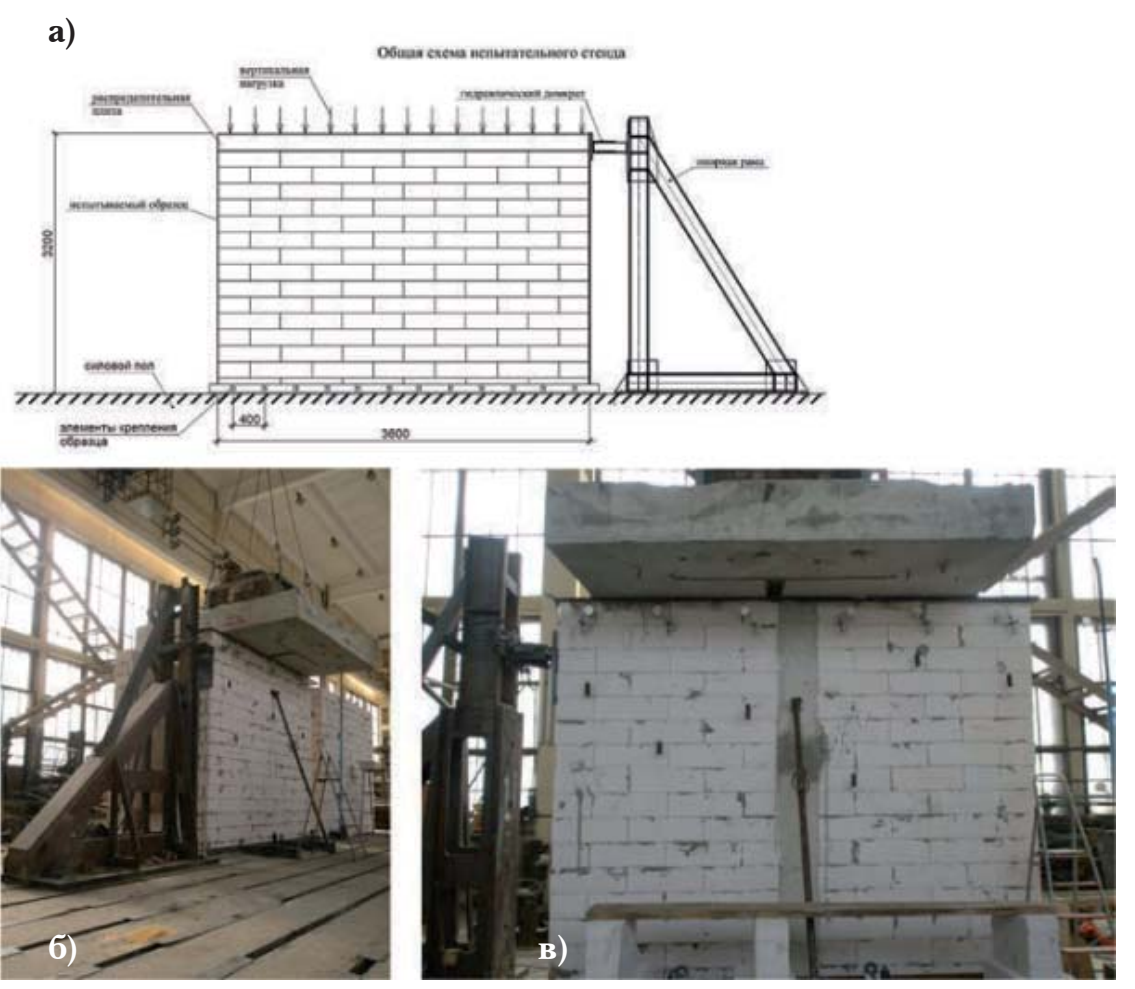

Рис. 3. Схема випробувального стенду з прикладенням горизонтального (сейсмічного) навантаження при монотонному навантаженні (а), загальний вигляд простінку без сердечника (б) і з сердечником (в), завантажених вертикальним та горизонтальним навантаженням 
міцністю на стиск не менше ніж С2,0 можливо лише з використанням залізобетонних сердечників висотою до 3-х поверхів в районах сейсмічністю 6 балів та висотою до 2-х поверхів при сейсмічності 7 балів.

3. Допустиме значення міжповерхових перекосів поверхів (табл. 6.8 ДБН В.1.1-12:2014 [1]) необхідно приймати не більше ніж 0,0004.

4. На основі результатів експериментальних досліджень для конструкцій 3 автоклавного газобетону при сейсмічності (7-8) балів приймають значення коеффіцієнта $k_{1}$ (табл. 6.3) рівним 0,5 .

Більш детально результати досліджень наведені в публікації [17].

Зміною № 1 ДБН В.1.1-12:2014 також внесені зміни до таблиці 6.4, що наведена у новій редакції, а саме:

«Таблиця 6.4 - Коефіцієнт $k_{2}$, що враховує тип і призначення будівлі (споруди)

\begin{tabular}{|c|c|c|}
\hline Ч.ч. & Характеристика споруд & Значення $\boldsymbol{k}_{2}$ \\
\hline 1 & $\begin{array}{l}\text { Особливо відповідальні та унікальні споруди, в тому числі виробничі } \\
\text { корпуси, складські будівлі хімічної промисловості } 3 \text { токсичними і } \\
\text { отруйними речовинами, вибухонебезпечні корпуси хімічно- } \\
\text { фармацевтичної промисловості і споруди нафтохімічної промисловості }\end{array}$ & 1,5 \\
\hline 2 & $\begin{array}{l}\text { Споруди з одночасним перебуванням великої кількості людей (великі } \\
\text { вокзали, аеропорти, театри, цирки, музеї, виставкові і концертні зали з } \\
\text { числом місць понад } 1000 \text { осіб, криті ринки та стадіони); } \\
\text { Будівлі та споруди, експлуатація яких необхідна при землетрусі або при } \\
\text { ліквідації його наслідків (системи енерго- і водозабезпечення, системи } \\
\text { пожежогасіння, телефонного і телеграфного зв’язків, виробничі корпуси } \\
\text { важкої промисловості з безперервним циклом роботи, банки, державні і } \\
\text { місцеві адміністративні органи тощо) }\end{array}$ & 1,4 \\
\hline 3 & $\begin{array}{l}\text { Будівлі та споруди лікарень на } 100 \text { ліжок и більше, пологових будинків, } \\
\text { акушерських корпусів, станцій швидкої допомоги, шкіл, дитячих садків, } \\
\text { вищих навчальних закладів, магістральних залізниць і автомобільних } \\
\text { доріг та штучних споруд транспорту }\end{array}$ & 1,3 \\
\hline 4 & Будівлі готелів, спальних корпусів для відпочинку на 250 місць і більше & 1,2 \\
\hline 5 & $\begin{array}{l}\text { Висотні споруди, невеликих у плані розмірів (башти, щогли, димові } \\
\text { труби, шахти ліфтів, що стоять окремо тощо) при відношенні висоти } \\
\text { споруди Н до їі ширини B, рівному або більше ніж 5, і великопрогонові } \\
\text { споруди }(\mathrm{L} \geq 30 \mathrm{~m})\end{array}$ & 1,4 \\
\hline 6 & $\begin{array}{l}\text { Каркасні будівлі, стінове заповнення яких не впливає на їх } \\
\text { деформативність, при відношенні висоти стійки «һ»до їі поперечного } \\
\text { розміру «b» в напрямку дії сейсмічного навантаження, рівному або } \\
\text { більше, ніж } 25\end{array}$ & 1,4 \\
\hline 7 & Те саме, але при h/b рівному або менше, ніж 15 & 1,0 \\
\hline 8 & Житлові, громадські та виробничі будівлі заввишки 73,5 м і вище & 1,4 \\
\hline 9 & $\begin{array}{l}\text { Житлові, громадські та виробничі будівлі, що не зазначені у рядках } \\
1-8 \text { цієї таблиці }\end{array}$ & 1,0 \\
\hline 10 & $\begin{array}{l}\text { Будівлі та споруди, руйнування яких не пов’язане із загибеллю людей, } \\
\text { втратою матеріальних і культурних цінностей і не викликає припинення } \\
\text { безперервних технологічних процесів або забруднення навколишнього } \\
\text { середовища (склади, кранові та ремонтні естакади, підприємства } \\
\text { торгівлі і побутового обслуговування з строком служби не більше } 20 \\
\text { років, невеликі майстерні, тимчасові будівлі та споруди, торговельні } \\
\text { павільйони тощо) }\end{array}$ & 0,5 \\
\hline \multicolumn{3}{|c|}{$\begin{array}{l}\text { Примітка 1. Споруди за рядком } 1 \text { цієї таблиці затверджуються відповідними центральними } \\
\text { органами виконавчої влади. } \\
\text { Примітка 2. За проміжних значень } h / b \text { значення } k_{2} \text { приймається за інтерполяцією. } \\
\text { Примітка 3. Коефіцієнт } k_{2} \text { повинен прийматися тільки один раз для будівель, зазначених в } \\
\text { рядках 3-5 цієї таблиці. }\end{array}$} \\
\hline
\end{tabular}


ДСТУ-Н Б ЕN 1998-1:2010 встановлює, що при визначенні сейсмічних навантажень на будівлі і споруди слід враховувати демпфуючі властивості конструкцій та обмежувати перекоси поверхів. Висотні будівлі мають знижені значення демпфування (у порівнянні з мало- та багатоповерховими будівлями), тому для підвищення сейсмостійкості висотних будівель коефіцієнт $k_{2}$ приймають рівним 1,4 (рядок 8 табл. 6.4 Зміни № 1 ДБН В.1.1-12:2014).

Зміною № 1 ДБН В.1.1-12:2014 внесені зміни до таблиці 6.8, що викладена у новій редакції:

Відповідно до таблиці 6.8 допустимі значення вані в будівництві житлових будинків до 5-ти поверхів за інтенсивності впливів 7 і 8 балів за умови забезпечення міцності цегли та керамічного каменю не нижче, ніж М 150 і міцності розчину не нижче, ніж М 75 в реальних умовах будівельного майданчика при відповідному контролю за цими показниками. У зонах із інтенсивністю сейсмічних впливів 9 балів слід застосовувати тільки суцільну цеглу;

б) камені бетонні, суцільні та пустотілі блоки 3 бетону (у тому числі з легкого, густиною не менше ніж 800 кг/м³) марки М 50 і вище;

«Таблиця 6.8 - Допустимі значення перекосів поверхів для трьох експлуатаційних рівнів

\begin{tabular}{|l|c|c|c|}
\hline \multicolumn{1}{|c|}{ Конструктивні схеми будівель } & \multicolumn{3}{|c|}{$\begin{array}{c}\text { Міжповерховий перекіс } \\
\text { для експлуатаційного рівня }\end{array}$} \\
\cline { 2 - 4 } & С3 & П3 & МР3 \\
\hline Сталевий каркас & 0,0067 & 0,012 & 0,02 \\
\hline $\begin{array}{l}\text { Залізобетонний каркас без вертикальних } \\
\text { діафрагм або ядер жорсткості }\end{array}$ & 0,0067 & 0,012 & 0,03 \\
\hline $\begin{array}{l}\text { Залізобетонний каркас з вертикальними } \\
\text { діафрагмами або ядрами жорсткості }\end{array}$ & 0,004 & 0,017 & 0,025 \\
\hline $\begin{array}{l}\text { Безкаркасні монолітні залізобетонні, } \\
\text { великопанельні і великоблочні }\end{array}$ & 0,0028 & 0,01 & 0,02 \\
\hline $\begin{array}{l}\text { Безкаркасні з кам'яними стінами або } \\
\text { армокам'яні }\end{array}$ & 0,0025 & 0,004 & 0,008 \\
\hline $\begin{array}{l}\text { Безкаркасні з несучими стінами з блоків із } \\
\text { ніздрюватого бетону автоклавного } \\
\text { тверднення }\end{array}$ & & \multicolumn{2}{|c|}{} \\
\hline Каркасно-кам'яні будівлі & 0,0025 & 0,004 & 0,008 \\
\hline Будівлі заввишки 73,5 м і вище & $\mathbf{0 , 0 0 2 5}$ & $\mathbf{0 , 0 1 2}$ & $\mathbf{0 , 0 1 5}$ \\
\hline
\end{tabular}

перекосів поверхів висотних будівель наведені для трьох експлуатаційних рівнів (С3, ПЗ і МР3). Вважаючи допустимі значення перекосів поверхів для будівель висотою 73,5 м і вище, необхідно враховувати додатковий момент від вертикальних навантажень в результаті горизонтальних нелінійних переміщень конструкцій будівлі під час землетрусу (пункти 6.3.6 і 6.3.7 ДБН В.1.1-12:2014).

Зміною № 1 ДБН В.1.1-12:2014 також внесені зміни до табл. 7.1 (рядок 9), що викладений у новій редакції.

Зміною № 1 ДБН В.1.1-12:2014 внесені зміни до пункта 7.10.2, що викладено у новій редакції, а саме:

«7.10.2 Для кладки стін дозволяється застосовувати:

а) за сейсмічності 6, 7 і 8 балів цеглу суцільну або порожнисту з пустотністю до $20 \%$ марки не нижче, ніж М 75. Керамічні вироби 3 пустотністю до $35 \%$ можуть бути застосо- в) камені та блоки правильної форми 3 черепашників або вапняків марки не нижче, ніж М 35 або туфів (крім фельзитового) та інших природних матеріалів марки М 50 і вище. Проектування житлових будинків 3 черепашників або вапняків виконують відповідно до вимог ДБН В.1.1-1;

г) розчини класу міцності на стиск не нижче, ніж М 50 на основі цементу 3 введенням пластифікуючих та/або спеціальних добавок, що підвищують зчеплення розчину з цеглою;

д) блоки із ніздрюватого бетону автоклавного тверднення класу за міцністю на стиск не менше, ніж С 2,0, з урахуванням положень 7.10.3. При проектуванні житлових будинків необхідно приймати середню густину виробів з урахуванням відпускної вологості бетону (коефіцієнт до власної ваги блоків слід приймати 1,35).».

Відповідно до пункту 7.10.2 Зміни № 1 ДБН В.1.1-12:2014 зниження процен- 
«Таблиця 7.1 - Поверховість житлових, громадських і промислових будівель в залежності від сейсмічності будівельного майданчика

\begin{tabular}{|c|c|c|c|c|c|}
\hline \multirow[t]{2}{*}{ Ч.ч. } & \multirow[t]{2}{*}{ Несучі конструкції будівлі } & \multicolumn{4}{|c|}{$\begin{array}{c}\text { Кількість надземних } \\
\text { поверхів при розрахунковій } \\
\text { сейсмічності будівельного } \\
\text { майданчика (бали) }\end{array}$} \\
\hline & & 6 & 7 & 8 & 9 \\
\hline 1 & Сталевий каркас & HC & HC & 16 & 12 \\
\hline 2 & $\begin{array}{l}\text { Залізобетонний каркас: } \\
\text { - } \quad \text { в’язевий або рамно-в'язевий із вертикальними } \\
\text { залізобетонними діафрагмами, в’язями або ядрами } \\
\text { жорсткості; } \\
\text { - } \quad \text { рамний із діафрагмами зі штучної кладки; } \\
\text { - } \quad \text { рамний без діафрагм; } \\
\text { - } \quad \text { безригельний із залізобетонними діафрагмами або } \\
\quad \text { ядрами жорсткості; } \\
\text { - безригельний без діафрагм }\end{array}$ & $\begin{array}{l}\mathrm{HC} \\
12 \\
16\end{array}$ & $\begin{array}{c}9 \\
7 \\
12\end{array}$ & $\begin{array}{l}7 \\
5 \\
9\end{array}$ & $\begin{array}{l}5 \\
3 \\
7\end{array}$ \\
\hline 3 & Стіни з монолітного залізобетону & $\mathrm{HC}$ & 24 & 20 & 12 \\
\hline 4 & Стіни великопанельні залізобетонні & $\mathrm{HC}$ & 20 & 16 & 10 \\
\hline 5 & Каркасно-кам’яні & $\mathrm{HC}$ & 10 & 7 & 5 \\
\hline 6 & $\begin{array}{l}\text { Стіни з великих бетонних або віброцегляних блоків: } \\
\text { - } \quad \text { дворядної розрізки, з'єднаних між собою за } \\
\text { допомогою закладних деталей або арматурних } \\
\text { випусків; } \\
\text { - дворядної розрізки, посилені суцільним } \\
\quad \text { вертикальним армуванням }\end{array}$ & $\mathrm{HC}$ & 5 & 4 & 4 \\
\hline 7 & $\begin{array}{l}\text { Стіни комплексної конструкції з цегли, природного } \\
\text { каменю і дрібноштучних стінових бетонних виробів }\end{array}$ & 12 & 5 & 4 & 3 \\
\hline 8 & $\begin{array}{l}\text { Стіни з цегли, природного каменю і дрібноштучних } \\
\text { стінових бетонних виробів }\end{array}$ & 9 & 4 & 3 & 2 \\
\hline 9 & $\begin{array}{l}\text { Стіни комплексної конструкції з використанням } \\
\text { стінових дрібних блоків з ніздрюватих бетонів класом за } \\
\text { міцністю на стиск: - С2.5 } \\
\text { - C } \mathbf{2 . 0}\end{array}$ & $\begin{array}{l}3 \\
3\end{array}$ & $\begin{array}{l}3 \\
2\end{array}$ & $\begin{array}{l}2 \\
-\end{array}$ & - \\
\hline 10 & Стіни дерев’яні щитові, рублені, брущаті & $\mathrm{HC}$ & 3 & 2 & 1 \\
\hline
\end{tabular}

Примітка 1. Вимоги до будівництва в 6-ти бальних зонах відповідно до 7.12.

Примітка 2. Висота поверху багатоповерхових будівель прийнята не більше 4 м для житлових і громадських будівель та 6 м для промислових.

Примітка 3. Позначення нс в таблиці вказує на те, що будівлі проектуються за вимогами для несейсмічних районів.

Примітка 4. Під першим поверхом в даних нормах мається на увазі об'єм, обмежений перекриттям, що лежить вище позначки защемлення будівлі в грунті. у кількості поверхів враховується також неповний поверх (машинні відділення ліфтових шахт тощо) у випадках, якщо його маса становить понад $30 \%$ нижче розташованого ярусу. Для житлових та громадських будівель кількість поверхів може бути збільшено, а також повинно бути зменшено згідно таблиці, якщо висота будівлі від позначки защемлення в грунті (наприклад, від позначки середньої планувальної відмітки) до позначки низу перекриття (покриття) не перевищує значення, рівного $(3.3 \times n+2.0)$ м, де $n-$ кількість поверхів (рядки 1-10).

Примітка 5. Кількість поверхів у будівлях з кам'яними стінами (рядки 7 і 8) при гарантованому нормальному зчепленні в кладці $f_{x k l} \geq 180$ кПа $(1,8$ кгс/см²) може бути збільшена в районах сейсмічністю 7 і 8 балів на один поверх. 
ту пустотності від $35 \%$ до 20\% пояснюється можливістю забезпечення безпеки застосування цегли і досягнення більш якісних показників такої кладки.

Також Зміною № 1 ДБН В.1.1-12:2014 внесені зміни до пункту 7.10.3, що викладено у новій редакції, а саме:

«7.10.3 Значення характеристичної міцності кам'яної кладки на вигин по неперев'язаних швах (нормальне зчеплення) має становити $f_{x k l} \geq$ 120 кПа.

У районах з інтенсивністю сейсмічних впливів 7 балів для малоповерхових житлових будівель, у разі розрахункового обгрунтування, допускається використання кладки з більш низьким значенням характеристичної міцності на вигин, але не менше ніж 60 кПа. При цьому висота будівель повинна бути не більше, ніж три поверхи, ширина простінків не менше, ніж 0,9 м, ширина прорізів не більше ніж 2 м, а відстань між осями поперечних стін не більше, ніж 12 м.

Будівництво житлових будівель 3 несучими стінами 3 блоків із ніздрюватого бетону автоклавного тверднення можливе за умови забезпечення та контролю в процесі зведення значення характеристичної міцності кладки на розтяг не менше, ніж 120 кПа для блоків марки D 400 за середньою густиною і класом за міцністю на стиск C 2,5 і 100 кПа для блоків марки D 300 за середньою густиною і класом за міцністю на стиск C 2,0.

Під час будівництва житлових будівель 3 несучими стінами комплексної конструкції з використанням стінових дрібних блоків з ніздрюватих бетонів (рядок 9 таблиці 7.1) необхідно застосовувати блоки класу за міцністю на стиск не менше, ніж C 2,5, за виключенням положень 7.10.3.2.

7.10.3.1 Будівництво житлових будівель з несучими стінами 3 блоків із ніздрюватого бетону автоклавного тверднення марки D 400 за середньою густиною і класом за міцністю на стиск C 2,5 допускається в районах із розрахунковою сейсмічністю 6 та 7 балів заввишки не більше, ніж 3 поверхи, 8 балів - не більше, ніж 2 поверхи 3 залізобетонними включеннями (сердечниками).

7.10.3.2 Будівництво житлових будівель з несучими стінами 3 блоків із ніздрюватого бетону автоклавного тверднення марки D 300 за середньою густиною і класом за міцністю на стиск C 2,0 допускається з залізобетонними включеннями (сердечниками) в районах із розрахунковою сейсмічністю 6 балів заввишки не більше, ніж 3 поверхи, 7 балів - не більше, ніж 2 поверхи.».

Нові положення пункту 7.10.3 і підпунктів 7.10.3.1 і 7.10.3.2 засновані на результатах експериментальних досліджень блоків із ніздрюватих бетонів автоклавного тверднення, що були проведені у ДП НДІБК протягом 2014 - 2016 років [17]. Відповідні основні результати експериментальних досліджень наведені вище.

\section{ВИСНОВКИ.}

Виконано аналіз положень сучасних нормативних актів у сфері сейсмостійкого будівництва різних країн, враховано накопичений досвід застосування нормативних актів України протягом 2016-2018 років, проведено масштабні експериментально-теоретичні дослідження.

Основними результатами впровадження Зміни № 1 ДБН В.1.1-12:2014 в сфері сейсмостійкого будівництва $є$ :

- актуалізація національної нормативної бази відповідно до сучасних завдань будівельної галузі та розвиток положень ДБН В.1.1-12:2014;

- врегулювання вимог щодо застосування карти загального сейсмічного районування 3СР-2004-С при проектуванні будівель і споруд із значним (СС3) класом наслідків (відповідальності);

- удосконалеення положень щодо проектування висотних житлових та громадських будівель;

- введення нових положень щодо проектування сейсмостійких малоповерхових будівель і споруд, що сприятимуть розширенню сфери застосування блоків із ніздрюватого бетону автоклавного тверднення.

\section{БІБЛІОГРАФІЧНИЙ СПИСОК}

1. ДБНВ.1.1-12:2014Будівництво усейсмічних районах України. - Чинні від 2014-1001. - Київ: ДП «Укрархбудінформ», 2014, $\mathrm{VI},-110 \mathrm{c}$.

2. Ghosh, S.K. State-of-the-Art in Precast Construction in USA. Associates Inc. - 54 p. Режим доступа: http://www. safecastproject.eu/index.php?option $=\mathrm{com}_{-}$ docman\&amp; task =cat_view\&amp; gid $=101 \&$ amp; Itemid $=53$.

3. Проектування сейсмостійких конструкцій відповідно до ЕВРОКОДУ 8. Практичний Посібник. Частина 1; за заг. ред. проф. Ю.І. Немчинова, ДП НДІБК, 2015. - Київ: ТОВ УЦРП. - 142 с.

4. ДСТУ Н Б ЕN 1998-1:2010 Еврокод 8. Проектування сейсмостійких конструкцій. Частина 1. Загальні правила, сейсмічні діï, правила щодо споруд (EN 1998-1:2004, IDT).

5. Немчинов Ю.И. Сейсмостойкость зданий и сооружений. В двух частях / Ю.И. Немчинов. - Киев, 2008. - 480 с.

6. ДСТУ Б В.1.1-28:2010 Захист від небезпечних геологічних процесів, шкідливих 
експлуатаційних впливів, від пожежі. Шкала сейсмічної інтенсивності. - Чинний від 2011-10-01. - Київ: ДП «Укрархбудінформ», 2011. - IV, 47 с.

7. ATC-40. Seismic Evaluation and Retrofit of Concrete Buildings - Volume 1 and 2, Applied Technology Council. Report No. SSC 96-01, Seismic Safety Commission, Redwood City, CA. - November, 1996.

8. FEMA 273. Federal Emergency Management Agency. NEHRP Guidelines for the Seismic Rehabilitation of Buildings, Washington, D.C. - October, 1997.

9. Fajfar, P. EERI M. A Nonlinear Analysis Method for Performance Based Seismic Design. "Earthquake Spectra", Vol. 16, No.3, August, 2000, pp. 573-592.

10. FEMA 356. Prestandard and commentary for the seismic rehabilitation of buildings. American Society of Civil Engineers (ASCE), Washington, D.C. - November, 2000.

11. Chopra, A.K. \& Goel, R.K. (2000). Capacitydemand diagram methods based on inelastic design spectrum // Proc. of $12^{\text {th }}$ World Conf. on Earthquake Engineering, Auckland, New Zealand, Paper № 1612.

12. Нормативные документы по сейсмостойкому строительству нового поколения Основные положения ДБН В.1.1-12: 2014: «Строительство в сейсмических районах Украины» с учетом рекомендаций европейского стандарта EN 1998-1 (ЕВРОКОД 8) и ДСТУ-Н Б В.1.2-16:2013 / Немчинов Ю.И., Марьенков Н.Г., Бабик К.Н., Хавкин А.К. и др. // Наука та будівництво, 2015, № 4. C. 4-11.

13. ДБН В.1.2-14-2009 Загальні принципи забезпечення надійності та конструктивної безпеки будівель, споруд, будівельних конструкцій та основ. Зміна №1 від 22.12.2011р. Наказ № 374 від 1 квітня 2012 p., 2009. - Київ: ДП «Укрархбудінформ». $37 \mathrm{c}$.

14. Закон України «Про об’єкти підвищеної небезпеки» від 18.01.2001 р., № 2245-III.

15. ДСТУ-Н Б В.1.2-16:2013 Визначення класу наслідків (відповідальності) та категорії складності об'єктів будівництва. - Чинний від 2013-09-01. - Київ: ДП «Укрархбудінформ», 2013. - III, 26 с.

16. ДБН В.1.2-5:2007 Система забезпечення надійності та безпеки будівельних об'єктів. Науково-технічний супровід будівельних об'єктів. - Чинні від 2008-01-01. - Київ: ДП «Укрархбудінформ», 2007. - 13 с.

17. Экспериментальные исследования несущих стен из газобетонных блоков D400 C2,5 и D300 C2,0 при вертикальных статических и горизонтальных сейсмических нагрузках / Немчинов Ю.И., Тарасюк В.Г., Марьенков В.Г., Жарко А.А. и др. // Наука та будівництво, 2017, № 2. - С. 10-18.

18. Проект трехэтажного жилого дома с несущими стенами из газобетона - «7-ми комнатный жилой дом «АРКА». - Киев: УкрНИИПГраждансельстрой, 2013.

19. Немчинов Ю.И. Сейсмостойкость высотных зданий и сооружений / Ю.И. Немчинов. Киев: Гудименко С.В., 2015. - 584 с.

\section{REFERENCES}

1. DBN B.1.1 -12:2014 Construction in seismic regions of Ukraine. - In force since 201410-01. - K.: SE «Ukrarkhbudinform», 2014, VI. -110 p.

2. Ghosh, S.K. State-of-the-Art in Precast Construction in USA. Associates Inc. - 54 p. Available at: http://www. safecastproject.eu/index.php?option $=\mathrm{com}$ docman\&amp; task=cat_view\&amp; gid= 101 \&amp; Itemid $=53$.

3. Design of structures for earthquake resistance in compliance with EUROCODE 8. Practical manual. Part 1. Under the general editorship of Prof. Iu. Nemchinov, NIISK, 2015. - Kyiv: TOV UTsRP. - 142 p.

4. DSTU-N B EN 1998-1:2010 Eurocode 8. Design of structures for earthquake resistance. Part 1: General rules, seismic actions and rules for buildings (EN 1998-1:2004, IDT).

5. Nemchinov Iu.I. Buildings and facilities earthquake resistance. In two parts. - Kyiv, 2008. - 480 p.

6. DSTU B V.1.1-28:2010 Protection against dangerous geological processes, harmful operational influences, against fire. Scale of seismic intensity. - In force since 2011-1001. - Kyiv: SE «Ukrarhbudinform», 2011. IV, 47 p.

7. ATC-40. Seismic Evaluation and Retrofit of Concrete Buildings - Volumes 1 and 2, Applied Technology Council. Report No. SSC 96-01, Seismic Safety Commission, Redwood City, CA. - November, 1996.

8. FEMA 273. Federal Emergency Management Agency. NEHRP Guidelines for the Seismic Rehabilitation of Buildings, Washington, D.C. - October, 1997.

9. Fajfar P., M.EERI. A Nonlinear Analysis Method for Performance Based Seismic Design. «Earthquake Spectra», Vol. 16, No.3, August, 2000, pp. 573-592.

10. FEMA 356. Prestandard and commentary for the seismic rehabilitation of buildings. American Society of Civil Engineers (ASCE), Washington, D.C. - November, 2000. 
11. Chopra, A.K. \& Goel, R.K. Capacity-demand diagram methods based on inelastic design spectrum // Proceedings of 12 World Conference on Earthquake Engineering, Auckland, New Zealand, 2000. Paper №1612.

12. Nemchinov, Iu.I., Marienkov, N.H., Babik, K.N., Dorofeev, V.S. etal. New generation regulatory documents on the earthquake resistant construction. Fundamental provisions of DBN V.1.-1-12: 2014 «Construction in seismic regions of Ukraine» with the allowance for the recommendations of the European Standard EN 1998-1 (EUROCODE 8) and DSTU-N B V.1.2-16:2013 // Science and Construction, 2015, No.4. - P. 4-11.

13. DBN V.1.2-14-2009. "The main principles of ensuring the structural safety of buildings, facilities, civil structures and bases». Amendment No.1 of 22.12.2011. Order No.374 of 01.04. 2012. - Kyiv: SE «Ukrarkhbudinform». - $37 \mathrm{p}$.

14. Law of Ukraine «On objects of higher risk» of 18.01.2001, No.2245-III.

15. DSTU-N B V.1.2-16:2013 Definition of consequences (responsibility) class and complication category of building sites. - In force since 2013-09-01. - Kyiv: SE «Ukrarkhbudinform», 2013. - III, 26 p.

16. DBN V.1.2-5:2007 System of building objects reliability and safety ensuring. Scientific and technical support of construction objects. - In force since 2008-01-01. - Kyiv: SE «Ukrarkhbudinform», 2007. - 13 p.

17. Nemchinov, Iu.I., Tarasiuk, V.H., Marienkov, N. H., Zharko, L.A. etal. The experimental investigations of bearing walls of D400 C2.5 and D300 C2.0 aerated concrete units under vertical static and horizontal seismic loads // Science and Construction, 2017, No.2. P. 10-18.

18. The project of a three-storey residential building with aerated concrete load-bearing walls. 7-room apartment building «ARKA». Kyiv: UkrNIIPHrazhdanselstroi, 2013.

19. Nemchinov, Iu.I. High-rise buildings and facilities earthquake resistance. - Kyiv: Gudymenko S.V., 2015. - 584 p.

Стаття надійшла в редакцію 14.05.2018 р. 